The nature of self

\title{
The nature of self and how it is experienced within and beyond the health care setting
}

\section{P Wainwright, F Rapport}

\section{The nature or self within and beyond the health care setting}

n his recent book "The healing tradition" David Greaves " , a former editor 1 of this journal, describes accompanying a hospital consultant on a ward round. He describes how the consultant, having been through the notes, charts, $\mathrm{x}$-rays, and lab reports, sat on the edge of the bed, took the patient's hand and asked "And how are you feeling in yourself?" To a lay person such a question may be unsurprising. We tend not to describe our feelings in a reductive way, certainly when it comes to illness rather than injury. We may have specific pains in our backs or knees or hips, but we are not usually conscious of pains in the liver or spleen and even "stomach ache" is actually a nonspecific complaint. And even when we can be more precise we tend, having discussed the specific problem, to move to a more general account. We say things like "The trouble is, it (whatever it is) makes you feel so rotten" and "you" here stands for "yourself" or "in your self". As Bruner suggests, "'self' is the common coin of our speech: no conversation goes on long without its being unapologetically used" (Bruner, p 63).

The human body may be reducible to its constituent parts and our ailments may be capable of being described by reference to very few points of data, but indicators such as the partial pressure of oxygen in the blood or the rate of clearance of creatinine by the kidney or the haemoglobin level tell us nothing, necessarily, about how the person feels, in his or her self. Not only do the patient and the clinician tend to have different frames of reference for the experience of illness or disease, the different accounts have different value. Toombs, describing her experience of multiple sclerosis (MS), describes suffering from a particular kind of muscular pain.

Various tests were performed culminating in a muscle biopsy. The initial pathology report indicated that there was a primary myopathic process going on but there was no explanation as to the cause. Since there was no clearcut definition of the problem, it was also not clear what therapy might be instituted to correct it. I was extremely discouraged by my inability to get around, by the continuing pain, and by the apparent inconclusiveness of the tests. In frustration I commented that, since the biopsy did not indicate what the problem was, nor what to do about it, we seemed to have gained little by performing the procedure. My physician replied "Oh but we have! Now we KNOW something is wrong". For me, as a patient, to know something was "wrong" was to be acutely aware of my bodily dysfunction and discomfort, and my inability to carry out the most mundane of activities. For the physician, to know that something was "wrong" was to have "objective" evidence in the form of an abnormal pathology report with respect to the muscle tissue removed from my thigh (Toombs, ${ }^{3}$ p 40).

Thus Toombs in herself had known all along that there was something wrong, but it was not sufficient that she felt something wrong in herself, medicine required objective evidence of malfunction at the microscopic level.

The body, then, can be reduced to its physical components, to no more than meat, but it is, as Evans memorably suggests, "meat with a point of view" (p 509). ${ }^{4}$ The consultant's question, "how do you feel in yourself?" is inviting the patient to express that point of view, and is inviting the kind of response that may be mediated by or reflect physiological changes - the patient with a low haemoglobin or a high urea level is very likely to feel pretty rotten - but that is not at the level of the biomedical analysis and represents an account that biomedicine may be singularly illequipped to accommodate.

The relationship between the self and health and illness seems, on one level, to be almost self evident. Lance Armstrong describes the day his testicular cancer was diagnosed:

I questioned everything: my world, my profession, my self. I had left the house an indestructible 25 year old, bulletproof. Cancer would change everything for me, I realised; it wouldn't just derail my career, it would deprive me of my entire definition of who I was. I had started with nothing... I had become something... Who would I be if I wasn't Lance Armstrong, world-class cyclist? (Armstrong, ${ }^{5}$ p 14)

Our sense of self, of who we are in ourselves and how we feel in ourselves, would seem to be a product of many factors. We can see something of this in the way Armstrong constructs his own identity, his own sense of self. He says:

I had started with nothing. My mother was a secretary in Plano, Texas, but on my bike, I had become something. When other kids were swimming at the country club, I was biking miles after school, because it was my chance. There were gallons of sweat all over every trophy and dollar I had ever earned... (Armstrong, ${ }^{5} \mathrm{p}$ 14)

Armstrong tells us something of his story and at the same time shows us how that story, as it unfolds, defines who he was and is and may become in the future. Some of the events were not of his choosing or under his control, others were, but all contribute to his self, his "entire definition of who I was". He starts life "with nothing" as the son of a secretary from Plano Texas, through his aptitude, ability, and extreme effort he becomes "Lance Armstrong, world class cyclist" and in the space of a few hours, between driving to the hospital and driving back, he becomes Lance Armstrong, cancer patient, "a sick person".

The idea for this themed edition of Medical Humanities came in part from a review, by Galen Strawson ${ }^{6}$ of a book by Jerome Bruner. In his book "Making Stories: Law, Literature, Life" (p 64) ${ }^{2}$ Bruner develops the argument that "we constantly construct and reconstruct our selves to meet the needs of the situations we encounter" (p 65) ${ }^{2}$ 
"Self-making is a narrative art" according to Bruner ( $p$ 65). Bruner writes:

A self is probably the most impressive work of art we ever produce, surely the most intricate. For we create not just one self-making story but many of them, rather like T S Elliot's rhyme 'We prepare a face to meet / The faces that we meet.' The job is to get them all into one identity, and to get them lined up over time. (Bruner, ${ }^{2}$ p 14).

But for Strawson this view is anathema. Developing his critique of Bruner and narrativity he says:

The further claim is that we create or invent the self specifically by "writing" and "storying" it. This idea has come to dominate vast regions of the humanities and human sciences - in psychology, anthropology, philosophy, sociology, political theory, literary studies, religious studies, and psychotherapy. Is any of this true? Do we create ourselves? Is the narrativity view a profound and universal insight into the human condition? ${ }^{6}$

Strawson claims that it is at best a partial truth, and later in the review he complains that:

Bruner never raises the question of whether there is any sense in which one's self-narrative should be accurate or realistic. Those who favour the extreme fictionalist or post-modernist version of the narrative selfcreation view don't care about this, both because they don't care about truth and because a fiction isn't open to criticism by comparison with reality (it doesn't matter that there is no Middle Earth). But honesty and realism about self and past must matter. There are innumerable facts about one's character and history that don't depend on one's inventions. One can't found a good life on falsehood. ${ }^{6}$

Leaving aside questions of what is meant by "accurate or realistic", it seems that Strawson is taking the narrative construction of self, Bruner's "storying", as no different from fiction, as if a story is inevitably or almost always a fiction. Armstrong's story and the self that emerges from that story do not "depend on [his] inventions" and in agreeing that Armstrong himself is a "work of art", a self made and perpetually rewritten story, we are in no sense committed to the assumption that this is a life founded on a deliberate falsehood.

In philosophy the self is a contested notion and we have no intention of attempting to settle the contest here. Strawson himself presents self experience as fundamental to human life, and defines it thus:

By 'Self-experience', then, I mean the experience that people have of themselves as being, specifically, a mental presence; a mental someone; a single mental something or other. Such Self-experience comes to every normal human being, in some form, in early childhood. The realization of the fact that one's thoughts are unobservable by others, the experience of the sense in which one is alone in one's head or mind, the mere awareness of oneself as thinking: these are among the very deepest facts about the character of human life (Strawson, ${ }^{7} p$ 104).

It is difficult to see how we are to make sense of self experience and the deepest facts about the character of human life other than in the context of the narrative within which that life is embedded. We may be able to make neutral, generalisable ontological statements about some abstract notion of the self as a kind of thing, "a kind of bare locus of consciousness, void of personality, but still for all that a mental subject" (Strawson, p 108). ${ }^{7}$ However, in the context of health care practice for example, one would want to include three other characteristics of the self that Strawson also discusses, but dismisses as unnecessary - the self as:

- a persisting thing, a thing that continues to exist across hiatuses in experience

- an agent

- something that has a certain character or personality.

Strawson argues that a minimal set of characteristics of the self does not need to include these three. In everyday life, however, we tend not to experience ourselves or the selves of others, Zenlike, as bare loci of consciousness, "void of personality". Human interaction is intimately bound up with these very characteristics, and any attempt to understand our selves and others, as people, as patients or as health care professionals, in varying forms or relations to each other, must necessarily take into account the unique particularity of the self and its story.
The papers in this issue, from a variety of perspectives, address the problem of self as experienced within and beyond the health care setting, offering commentaries on how the self can be constructed, whilst illuminating the unique selves of the writers. We open with a paper by Nigel Rapport, who considers the life of the painter Stanley Spencer in terms of self-artistry and the projected self. Concentrating on "The existential power of individuals to create and lead their own lives", Rapport describes Spencer's ability to construct a social environment, through creative output, that is created predominantly in his own image. Striving to be his own man, suggests Rapport, is both "life creating" and enhancing of others' lives. Elizabeth Kinsella offers a general overview of how the self is constructed through three perspectives - the unitary, the fragmented and the dialogical. Kinsella encourages us to examine ethical relationships and the inter-subjectivities that come to light when we engage with others, reflected in the inter-subjective practices of healthcare professionals. These first two papers lay the grounds for three broad themes: a) constructions of self through the body, b) constructions of self through the mind, and c) patients, professionals, and sense of self.

The self as embodied is explored in the writings of: Annabelle Mooney (HIV narratives), Andrew Sparkes, Brett Smith (elite sport and the traumatised body), and Jennifer Bullington (the ageing body). Mooney views the body as the essential property of our existence, defined in both its explicit and implicit aspects. She describes her HIVpositive respondent's inward and outward portrayals of a stigmatised existence, concluding that our inward mechanisms of story telling are often surmised rather than explicit in our stories. Mooney reveals the feared and unspoken aspects of illness narrative, suggesting that "What is feared is the way in which others will write his illness on his body", and offers insights into the spoken and unspoken understandings we give to health and illness. Sparkes and Smith develop ideas surrounding the embodied self through analysis of interviews with sportsmen disabled by spinal chord injury. Using the concepts of metaphor, notions of time and different kinds of hope, as well as the application of Frank's chaos, quest and restitution narratives, Sparkes and Smith argue that experience is shaped by the lives we lead, represented by spoken narratives that convey "the profundity of human experience". 
The relationship between mental illness and the construction or maintenance of self are explored by David Roe and Larry Davidson, who consider the experience of schizophrenia, disruption to selfhood, and the recreation of the life-story through recovery from illness. Roe and Davidson suggest that reauthoring of life is an integral process towards illness recovery and although life events can be fragmented for the person suffering from schizophrenia, a strong sense of self can be recovered in time.

Don Flaming writes about the role of patients and professionals from the medical and lay perspectives. Don Flaming moves from the patient to the professional agenda when he examines the experience of becoming a professional nurse, Flaming applies Ricoeur's understanding of narrative and 'mimesis' to offer a reflexive presentation of ten nurse students' experiences. Flaming discusses continuity of experience from past through present to anticipated future and considers the self to be "Made up of a mixture of past identities that play an integral role in present understanding and experience". The last paper in this issue is by Alistair Campbell and Michaela Willis, reflecting on professional and patient orientations to self and the difference between medical and lay positions. Taking the example of the post-mortem retention of children's organs, Campbell and Willis suggest that different discourses serve different purposes in the health and illness arena. Medical discourse is a functional discourse pertaining to scientific goals, whist lay understanding is based on shared human experience and the embodied self:

These papers come together through their use of constructions of self in health and illness narratives in their vision of the self as repairable through the telling and re-telling of the story. Central to all these accounts is the importance of the "point of view" of the person whose self is at stake. This is not about Strawson's bare loci of consciousness, "void of personality". It is, rather, about the interaction between our interests, our preferences and our relationship with and responses to the events in our lives. The authors in this issue concentrate on self-control and self-determination, though they may differ in their responses to the ability of individuals to 'write' their own narratives. Rapport, for example, argues for "The existential power of individuals to create and lead their own lives", whilst Campbell and Willis point to "A gulf between medical and lay understandings of the human body and its relationship with the human person". The writers grapple with the relationship between body, mind and self and much time is spent deliberating on the embodied nature of self. Authors question whether the body is quintessentially linked to a sense of self and selfhood: as Mooney suggests, as humans we are embodied but we are not reducible to our bodies. However, Mooney goes on to reflect that our bodies are an "Essential property of our existence". The authors of these papers frequently adopt an emotive and reflexive style. Flaming, for example uses reportage to convey the words and feelings of others and there are many examples of emotive writing styles as writers consider the narratives of their study participants. Sparkes and Smith concentrate on the mood of the participants they interviewed: "In chaos Jamie feels swept along, without control, by life's fundamental contingency" and Mooney, in an attempt to stay true to her participant's presentation comments: "I quote John at length in an attempt to give voice to his story" (p.8).

This body of work would seem to support Bruner's claim that "there is no such thing as an intuitively obvious and essential self to know, one that just sits there ready to be portrayed in words" ( $p$ 64). He goes on: "Self-making is, after all, our principle means for establishing our uniqueness, and a moment's thought makes plain that we distinguish ourselves from others by comparing our accounts of ourselves with the accounts that others give us of themselves" (p 66). ${ }^{2}$

If we accept this view of the self as constructed, we must also be aware of the impact of the events in our lives that shape the selves that we are and that we become. My self as health care professional, as academic, and as patient coexist together and alongside the many other facets of my self. The papers in this edition of the journal offer rare insight into the nature of the self and its construction.

$J$ Med Ethics; Medical Humanities 2005:31:57-59.

doi: 10.1136/jme.2005.2005.000219

Authors' affiliations

Paul Wainwright, Professor of Nursing, Kingston University and St George's University of LondonFaculty of Health and Social Care Sciences, Kingston Upon Thames, Surrey, UK

Frances Rapport, Julian Tudor Hart Senior Research Fellow, Primary Care Group, Swansea Clinical School, University of Wales Swansea, Swansea, UK

Correspondence to: Professor Paul Wainwright, Kingston University and St George's University of London, Faculty of Health and Social Care Sciences, Sir Frank Lampl Buiilding, Kingston Hill, Kingston Upon Thames, Surrey KT2 7LB, UK; pwainwri@hscs.sgul.acuk

\section{REFERENCES}

1 Greaves D. The healing tradition: reviving the soul of Western medicine. Oxford, Raddliffe. 2004.

2 Bruner J. Making stories: law, literature, life. New York, Farrar. 2002

3 Toombs S K. The meaning of illness: a phenomenological account of the different perspectives of physician and patient. London Kluwer. 1993:40.

4 Evans $M$. Reflections on the humanities in medical education. Med Educ 2002;36:508-513.

5 Armstrong L. It's Not About The Bike: My Journey Back to Life. London, Yellow Jersey Press. 2001.

6 Strawson G. Book Review: Tales of the unexpected. http://books.guardian.co.uk/ review/story/0,12084,1 $118942,00 . \mathrm{html}$ (Accessed 11 Óctober 2005).

7 Strawson G. The self and the SESMET. Journal of Consciousness Studies 1999;6:99-135. 